\title{
Auto-ecological responses of rainbow trout populations to ecoregional differences in a neotropical Andean river
}

\author{
Francisco Javier Luque* and Juan David González-Trujillo
}

\author{
M. Sc. Biología. Departamento de Biología, Universidad Nacional de Colombia. Carrera 30 \# 45 - 03, Edificio \\ 421, Of. 110. Bogotá. \\ * Corresponding author: fjluquem@unal.edu.co
}

Received: 30/11/18 Accepted: 20/12/19

\begin{abstract}
Auto-ecological responses of rainbow trout populations to ecoregional differences in a neotropical Andean river

We assessed changes in auto-ecological traits of Rainbow Trout (Oncorhynchus mykiss) in a river flowing through two ecoregional belts. Besides the temperature and elevation, these ecoregional belts mainly differed in terms of the presence or absence of riparian forest (high-Andean and páramo regions, respectively). Our results indicated that fish populations in the páramo attained sexual maturity at a smaller size and fed mainly on autochthonous small aquatic invertebrates such as chironomid midges and caddisflies. In the high-Andean reach, Rainbow Trout attained larger sizes and there was a segregation in the use of food resources; adults fed primarily on allochthonous resources and juvenile fish on autochthonous prey items. Overall, our results suggested that limited availability of resources did not constrain the successful establishment of Rainbow Trout in Andean streams but appeared to have a direct effect on some auto-ecological characteristics such as sexual maturity, size and diet. The variability of the evaluated traits seemed to be linked to the presence or absence of resources provided by a well-developed riparian forest, instead of variability in temperature, water quality or flow regime.
\end{abstract}

Key words: allochthonous, autochthonous, diet, high-Andean stream, Páramo, Colombia

\section{RESUMEN}

Respuestas auto-ecológicas de las poblaciones de trucha arcoíris a las diferencias ecorregionales en un río andino Neotropical

En este estudio evaluamos los cambios en los rasgos auto-ecológicos de la trucha arcoiris (Oncorhynchus mykiss) en un rio que fluye a través de dos cinturones ecorregionales (Altoandino y Páramo). Además de la temperatura y la altitud, estos cinturones ecorregionales difieren principalmente en términos de la presencia y ausencia "natural" de bosques de ribera (altoandino y páramo, respectivamente). Nuestros resultados indicaron que las poblaciones del páramo alcanzan la madurez sexual a un tamaño más pequeño y se alimentan principalmente de pequeños invertebrados acuáticos, como larvas de quironómidos y frigáneas. En la región altoandina, por otra parte, las truchas arcoiris alcanzaron tamaños mayores y evidenciamos una segregación en el uso de los recursos alimenticios, donde los adultos se alimentaron principalmente de recursos alóctonos y los juveniles de presas autóctonas. En términos generales, nuestros resultados sugieren que una disponibilidad limitada de recursos no limita el establecimiento de la trucha arcoiris en los ríos altoandinos, sino que parece tener un efecto directo sobre algunas de sus características autoecológicas como la madurez sexual, el tamaño y la dieta. Esta variabilidad observada en los rasgos auto-ecológicos parece estar vinculada a la presencia y ausencia de recursos provistos por un bosque ribereño bien desarrollado, en lugar las características de temperatura, calidad del agua o régimen hidrológico de cada ecorregión.

Palabras clave: alóctono; autóctono, dieta, río altoandino, Páramo, Colombia 


\section{INTRODUCTION}

The Rainbow Trout (Oncorhynchus mykiss, Walbaum 1792) is a species native to the west coast of North America, ranging from northwest Mexico to southwest Alaska and the Kamchatka Peninsula in eastern Russia (Behnke, 1992). The species has been introduced worldwide for aquaculture purposes and recreational fisheries (Rahel, 2000; Fausch, 2007). Its introduction has reduced several populations of native fishes and altered the natural dynamics of invertebrate populations in New Zealand, Australia, Japan, South Africa, Chile and Argentina (Macchi et al., 1999; Cambray, 2003; Simon \& Townsend, 2003; Kitano, 2004; Soto et al., 2006). In light of its potential impact, understanding which factors affect trout ecology and population dynamics has been a priority for researchers for the past several years (e.g. Flecker \& Townsend, 1994; Townsend, 2003; Fausch, 2007; Soto et al., 2006). Nevertheless, while the Rainbow Trout was introduced in the 1930s to "repopulate" Andean streams in the Neotropical region (Segnini \& Bastardo, 1995; Pascual et al., 2002; Pineda et al., 2004), few studies have addressed how the auto-ecology of trout populations might change as a consequence of the distinctive features of these ecosystems.

Generally, most high-altitude streams flow through two distinct ecoregional belts in the tropical Andes, the páramo and high-Andean ecoregions. These ecoregions differ mainly in terms of elevation and climate, as first noted by Alexander Von Humboldt (Humboldt \& Bonpland, 1805). The high-Andean ecoregion is located below $3000 \mathrm{~m}$ s.a.l., which is usually where the Andean Forest belt ends (IDEAM, 2010). This ecoregion has relatively stable temperature conditions throughout the year, and its riparian forests are composed mainly of shrubs and leafy trees (Rangel-Ch et al., 1997; Morales et al., 2007). The páramo ecoregion has extreme temperature variations, soils with high water retention capacity as well as endemic vegetation assemblages. The páramos vegetation, beginning above $3000 \mathrm{~m}$ a.s.l, is chiefly comprised of giant rosette plants (Espeletia spp.), shrubs, and grasses (Buytaert et al., 2006).
The patchy riverscape emerging from these ecoregional differences can be appreciated in a longitudinal dimension: high-altitude streams flow throughout the páramo regions and have no canopy cover before entering the well-forested zones characteristic of high-Andean regions. To date, few studies have addressed how these ecoregional differences might affect the structure and dynamics of riverine populations.

Streams and riparian forest are ecosystems closely linked by the input of allochthonous material (Baxter et al., 2004, 2005). The terrestrial arthropods that accidentally fall into streams, for instance, represent not only high-quality food resources for fishes (Wipfli, 1997) but also energy inputs for maintaining food-web structure (Nakano et al., 1999). The input of allochthonous material, associated with a well-developed riparian forest, appear to be the most relevant factors for explaining trout distribution in forested streams (Polis et al., 1997; Vimos et al., 2015). However, in the natural absence of allochthonous inputs, such as in the páramo ecoregion, fish might be deprived of these energetic sources, limiting their development and survival opportunities. Therefore, the increasing quality and quantity of allochthonous inputs as rivers enter to the high-Andean ecoregion could be one of the major factors influenc-

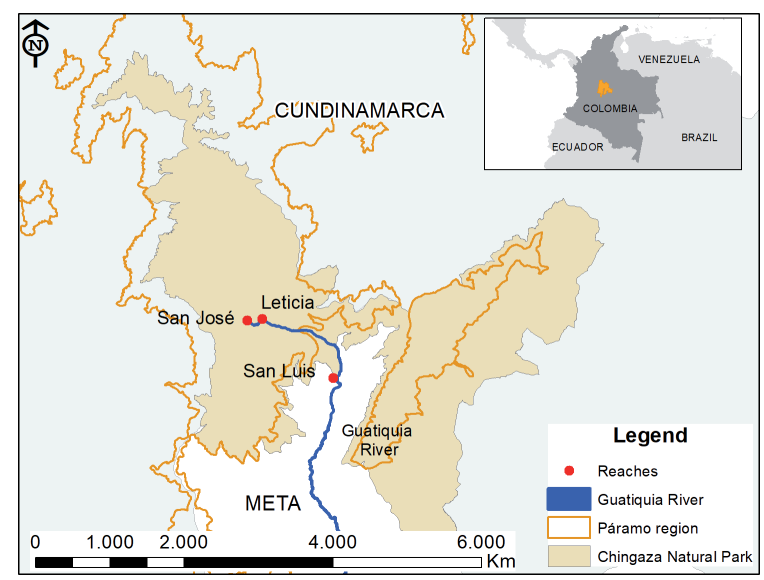

Figure 1. Map of sampled reaches, showing the páramo region at Chingaza Natural Park. Mapa de los tramos muestreados, mostrando la región de Páramo en el Parque Nacional Natural Chingaza. 
ing the auto-ecology and distribution of fishes along high-Andean rivers.

The aim of this study was to assess how auto-ecological traits of Rainbow Trout change due to ecoregionally-driven differences along a high-Andean river. This assessment included the description of some auto-ecological features (i.e., diet, feeding strategy, and sexual maturity) and their possible relationships with the presence of a well-developed forest in the high-Andean ecoregion. We expected that the diet and related auto-ecological traits of Rainbow Trout would change among sites on páramo and high-Andean reaches responding to differences in the input of allochthonous material, mostly terrestrial invertebrates.

\section{MATERIALS AND METHODS}

\section{Study site}

The Guatiquía River is a Strahler third order stream formed by the union of three small streams at an elevation of $3500 \mathrm{~m}$. The river flows through the páramo ecoregion for approximately $20 \mathrm{~km}$ until it enters the high-Andean ecoregion. In the páramo, two reaches were sampled, "San José" (3180 m a.s.1; 04 32' 19.5" $\mathrm{N}, 73^{\circ} 44^{\prime} 40.5^{\prime} \mathrm{W}$ ) and "Leticia" (3030 $\mathrm{m}$ a.s.1; $04^{\circ} 32^{\prime}$ 24.1" N, 37 43' 51.4" W) (Fig. 1). The riverbed of these two reaches is dominated by boulders, cobble and gravel, and their riparian vegetation consists mainly of shrubs, such as Polylepis sp. (Rosaceae), Hypericum sp. (Hypericaceae) and Chusquea tessellate (Poaceae), grasses like Calamagrostis sp. (Poaceae) and mosses such as Sphagnum sp. (Sphagnaceae). A third reach was sampled in the high-Andean ecoregion: "San Luis" (1850 m a.s.1; 04 29' 9.6" $\mathrm{N}, 73^{\circ} 39^{\prime}$ 58.2" W) (Fig. 1). Its riverbed is also composed by gravel, boulders and sand, but its riparian vegetation comprises primarily two strata: a tree layer composed of Ficus sp. and Cecropia sp., shrub species of Melastomataceae and Moraceae, and a ground layer composed of species of Araceae, Ericaceae and ferns. The three reaches are generally exposed to low anthropogenic stress because they are inside a protected area (Chingaza National Natural Park).

\section{Fish sampling}

At each reach, we sampled the fish communities during daylight (from 8 to $16 \mathrm{~h}$ ) in three occasions: July and November 2013 and January 2014 (high, intermediate and low water flows, respectively). Sampling reaches were approximately 80 - $100 \mathrm{~m}$ in length. We measured temperature, dissolved oxygen, conductivity and $\mathrm{pH}$ using a $\mathrm{HACH} \mathrm{Hq} \mathrm{multiparameter} \mathrm{probe} \mathrm{upon} \mathrm{arrival}$ (early morning) and departure (dawn) from each reach. The number of reaches and their length were constrained by difficult access to the river. Inside the park, few reaches are accessible without compromising the security and integrity of the field crew because of the steep topography of the river margins. We used non-parametric Kruskall-Wallis tests (with a significance level of $\alpha=0.05$ ) to assess the significance of the differences between reaches in terms of environmental characteristics.

We collected samples by electrofishing (Smith-Root 1.5 KVQ and Honda generator 3 $\mathrm{Kw})$ with three passes per reach. The reaches were not blocked because of the river's high flow (minimum of $3 \mathrm{~m}^{3} / \mathrm{s}$ ). Following capture, we sacrificed all fish using a MS-222 overdose. We measured fish standard length $(0.01 \mathrm{~mm})$ and weight $(0.01 \mathrm{~g})$ in the field. After measurements, we preserved fish in $96 \%$ ethanol and transported them to the ichthyology laboratory at the Instituto de Ciencias Naturales ("ICN" - Universidad Nacional de Colombia). In the laboratory, sex and gonadal development (juvenile or adult) were determined by direct observation of the gonads after gut removal. A one-way ANCOVA was conducted to determine statistically significant difference between páramo and high-Andean reaches on the somatic condition of trout individuals controlling for length. An $\alpha<0.05$ was established to determine a significant effect.

\section{Aquatic invertebrate sampling}

We sampled invertebrate assemblages before fishing. Samples were taken in gravel and boulder substrates to complement fish diet characterization. We took five random samples in each type of substrate with a Surber $\left(0.09 \mathrm{~m}^{2}, 200 \mu \mathrm{m}\right.$ 
mesh size). The area of the sampled boulders was equal or inferior to a Surber sampling area. We took a total of 90 samples (3 occasions x 3 reaches $x \quad 2$ substrates $x \quad 5$ samples) and preserved each sample individually in $96 \%$ ethanol. In the laboratory, we sorted all individuals and identified them to family level following Domínguez and Fernández (2009) and Prat et al. (2011). We carried out the sampling of aquatic invertebrates, fish community, and water physical and chemical properties in parallel during all sampling occasions.

\section{Diet characterization}

In the laboratory, we dissected the fish specimens to remove their complete digestive system. We gathered food items from each stomach and preserved each item in $96 \%$ ethanol. We identified all arthropods from the stomachs to family level following Domínguez and Fernández (2009) and Prat et al. (2011) for aquatic invertebrates, and Johnson and Tripplehorn (2005) for terrestrial invertebrates.

We described diet composition in terms of prey occurrence $\left(F_{i}\right.$, eq.1) and prey-specific abundance $\left(P_{i}\right.$, eq.2) of prey items (Hyslop, 1980; Amundsen et al., 1996):

$$
F i=N i / N \quad \text { (equation 1) }
$$

Where, $N_{i}$ is the number of stomachs with the prey item $i$, and $N$ is the total number of stomachs with at least one prey item.

$$
P i=(\Sigma S i / \Sigma S t i) \times 100 \quad \text { (equation 2) }
$$

Where, $P_{i}$ is the prey-specific abundance of prey $i, S_{i}$ the number comprised by prey $i$, and $S_{t i}$ the total content in only those predators with prey I in their stomach (Amundsen et al., 1996).

\section{Data analysis}

We explored diet composition differences among reaches through a non-metric multidimensional scaling (nMDS) using the Morisita-Horn index (Morisita, 1959; Horn, 1966). We used this index because it is a measure weighted towards the dominant species (Jost et al., 2011). Therefore, we could compare diet composition without giving too much importance to incidental prey items such as some allochthonous taxa that occasionally fell into the river. We did not include families with five or less individuals in the ordination analysis. We performed analyses and graphical outputs using the statistical program $\mathrm{R}$ v3.2.1 (R Core Team 2015 - software available at http://www.R-project.org). We performed the nMDS by using the 'metaMDS' function of the 'vegan' package. We set all parameters of this function as default. We used the program ArcGIS 10.3 to create Fig 1.

Table 1. Physical and chemical values of the water of the studied reaches. Mean value and standard error in parenthesis. Only comparisons with $p$-values $<0.05$ were considered as statistically significant. KW: Kruskal-Wallis test. Valores fisicos y químicos del agua en los tramos estudiados. Valor promedio y error estándar en paréntesis. Solo las comparaciones con valores $\mathrm{p}<0.05$ fueron considerados estadísticamente significativas. $K W$ : análisis Kruskall-Wallis.

\begin{tabular}{lcccc}
\cline { 2 - 4 } Temperature $\left({ }^{\circ} \mathrm{C}\right)$ & San José & Leticia & San Luis & \\
\hline Dissolved Oxygen $(\mathrm{mg} / \mathrm{L})$ & $7.57(0.14)$ & $7.33(0.04)$ & $8.13(0.03)$ & $\begin{array}{r}\mathrm{KW} \text { Chi-squared }=0.62, \\
\mathrm{df}=2, p \text {-value }=0.73\end{array}$ \\
Conductivity $(\mu \mathrm{S} / \mathrm{cm})$ & $36.33(2.94)$ & $40.93(3.72)$ & $76.50(3.84)$ & $\begin{array}{r}\mathrm{KW} \text { Chi-squared }=8, \\
\mathrm{df}=2, p \text {-value }=0.02 \\
\mathrm{KW} \text { Chi-squared }=5.9, \\
\mathrm{pH}\end{array}$ \\
\hline
\end{tabular}




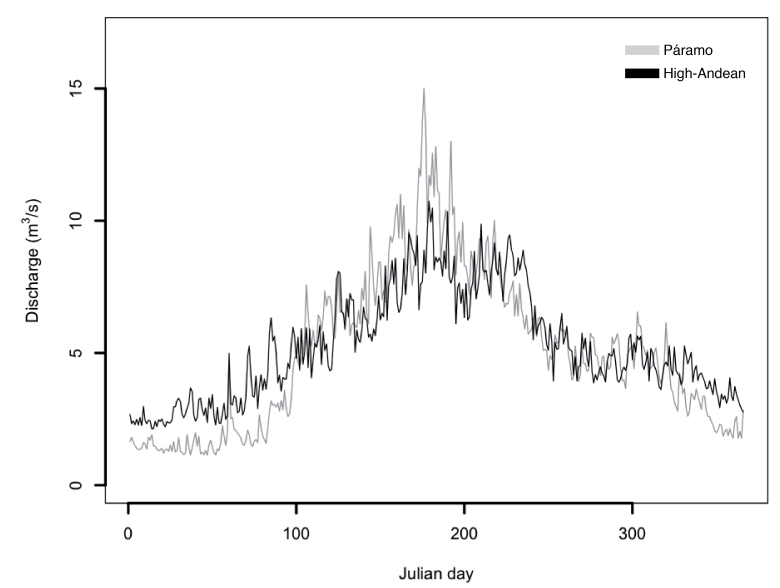

Figure 2. Daily average discharge of páramo (grey) and high-Andean reaches from the Guatiquía River. Data series from 2000 to 2013, were provided by the "Empresa de Acueducto y Alcantarillado de Bogotá". Promedio diario del caudal de los tramos de Páramo (gris) y alto-andinos del río Guatiquia. Serie de datos desde 2000 hasta 2013, provisto por la "Empresa de Acueducto y Alcantarillado de Bogotá”.

\section{RESULTS}

Water conductivity was statistically different among the three sampled reaches (Table 1). The temperature tended to be higher at Leticia, on the páramo ecoregion, but its mean value was not statistically different from the other reaches: San Jose (páramo) and San Luis (high-Andean) (Table. 1). Dissolved oxygen, $\mathrm{pH}$ and flow history were similar between the selected reaches (Table. 1, Fig. 2). We only observed differences in the base-flow magnitude during the dry season (December to February); the base-level of the high-Andean reach was slightly greater than in the páramo reaches.

Fish sampling efforts captured a total of 138 individual trout: 78 at the páramo reaches (mean standard length $=104.01 \pm 32.07 \mathrm{~mm}$, mean weight $=19.96 \pm 13.41 \mathrm{~g})$ and 60 at the high-Andean reach (mean standard length $=121.6 \pm$ $29.25 \mathrm{~mm}$, mean weight $=39.32 \pm 29.25 \mathrm{~g}$ ). Two individuals of the small catfish - locally known as Barbillo (Astroblepus micrescens, Eigenmann 1918) were also captured at the high-Andean reach. The direct observation of gonadal development showed that trout reach sexual maturity

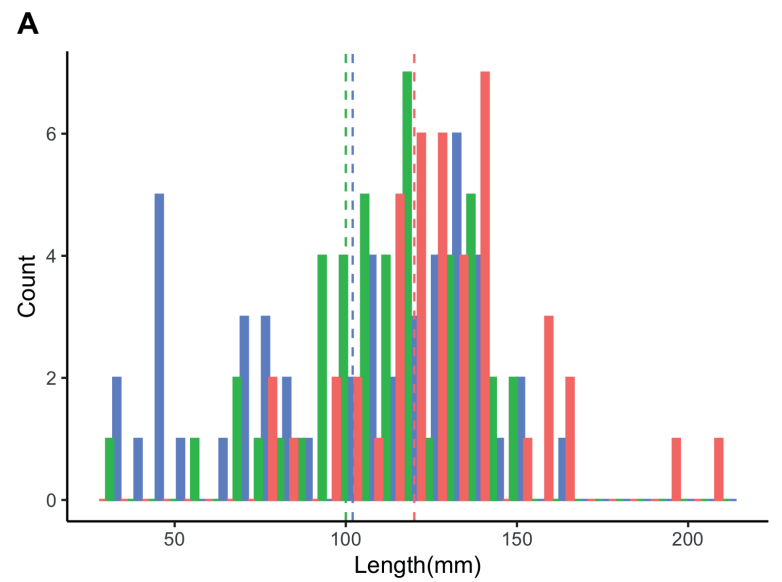

B

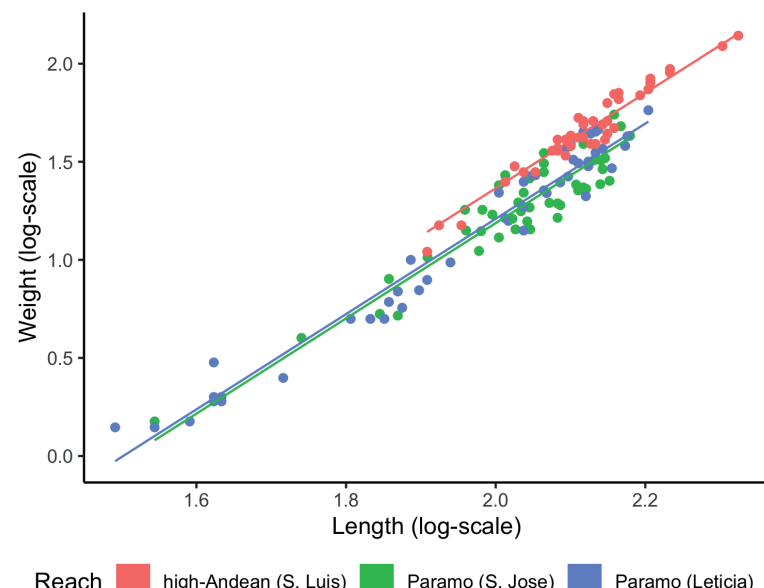

Figure 3. Size (A) distributions of Rainbow Trout populations at the three reaches. The dotted line highlights the size-at-maturity values of trout at each reach. C- Linear relationships between the logarithmically transformed weights and lengths of trout at the three studied reaches. Distribución de tallas (A) de las poblaciones de trucha arcoiris en los tres tramos. La linea punteada señala la talla de maduración de las truchas en cada uno de los tramos. C-Relaciones lineales entre los pesos y longitudes de las truchas, transformados logaritmicamente en los tres tramos estudiados.

at a short standard length. Sexual maturation was reached at $100 \mathrm{~mm}$ in the páramo reaches and at $120 \mathrm{~mm}$ in the high-Andean reach. Mature females presented well-developed ovaries containing fully formed oocytes, immature females presented long string-like ovaries without oocytes. On the other hand, mature males presented extended testes, while immature males presented long and thin testes. We observed pres- 
ence of milt in two mature males during the intermediate water flow season (November 2013).

The distribution of trout sizes varied across ecoregions. Populations from the páramo were composed mainly of adult individuals that rarely exhibited standard lengths over $150 \mathrm{~mm}$. Meanwhile, the number of juvenile individuals was higher in the high-Andean reach, where less than half of the captured trout had reached adulthood. This is because size-at-maturity is very different among reaches, being notably larger in the high-Andean reach (Fig. 3A). Adult individuals reached significantly bigger sizes than in the páramo. Indeed, the biggest individual was found in this reach $(210 \mathrm{~mm}$ and $138 \mathrm{~g})$. Trout inhabiting the high-Andean reach had a significantly higher somatic condition than in those occupying páramo reaches $(\mathrm{F}(1,2)=46.65, p<0.01$; Fig. $3 \mathrm{~B})$. This shows that there is a significant effect of ecoregion type on the trout weight after controlling for individuals' length.

\section{Diet Composition}

We identified a total of 70 families from the gut contents of Rainbow Trout populations. Trout diet included a broad array of aquatic and terrestrial invertebrates. However, trout did not consume all the aquatic families that inhabit each reach. In the páramo region (S. José and Leticia reaches), trout fed primarily on aquatic larvae of Diptera (mainly chironomids) and Trichoptera, while in the high-Andean region trout diet was dominated by allochthonous invertebrates and
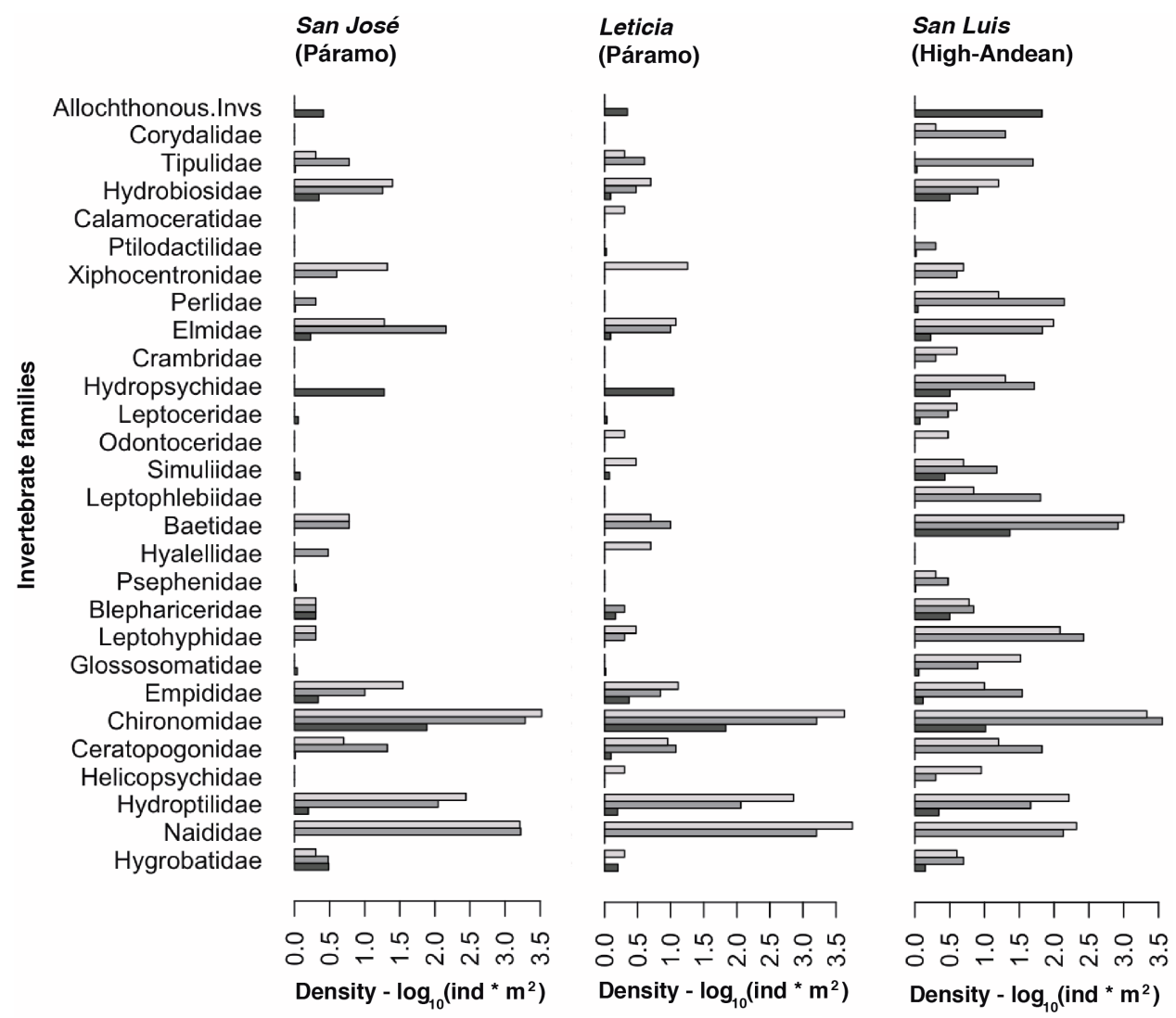

Figure 4. Mean density of invertebrate families (individuals per square meter - log10 transformed) found on two distinct substrates of the river (Boulder - light-grey; Gravel - dark-grey) and in the trout stomach (individuals per stomach-black). Densidad promedio de las familias de invertebrados (individuos por metro cuadrado - transformado por log10) encontradas en dos substratos diferentes (Rocas - gris claro; Grava - gris oscuro) y en el estómago de las truchas (individuos por estómago - negro). 


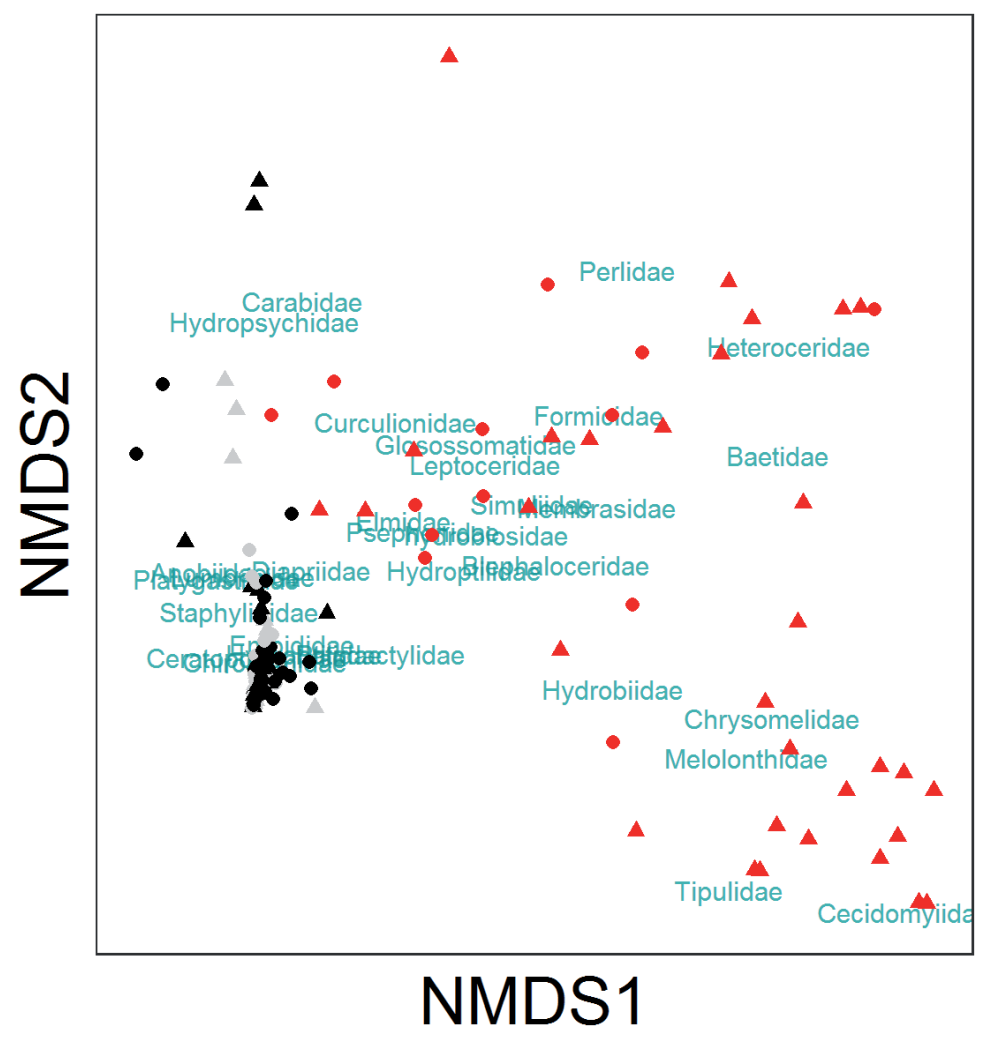

Figure 5. Ordination plot of trout according to their diet composition using a non-Metric Multidimensional Scaling (nMDS) technique. Páramo reaches are represented in black and grey, the high-Andean reach in red. Triangles represent mature trout and circles refer to inmature trout. Stress $=0.1018$. Distance $=$ Horn-Morisita. Ordenación de las truchas de acuerdo a la composición de la dieta usando un Escalamiento Multidimensional no Métrico (nMDS). Los tramos de páramo están representados en negro y gris, el tramo alto-andino en rojo. Los triángulos representan las truchas maduras y los círculos las truchas inmaduras. Estrés $=0.1018$. Distancia $=$ Horn-Morisita .

larvae of Diptera, Trichoptera and Ephemeroptera (Fig. 4). Some highly abundant invertebrates were rarely found in trout stomachs (Fig. 4). This result might be a consequence of several invertebrate characteristics, including small size (e.g. Naididae, Ceratopogonidae and Hydroptilidae), sclerotized exoskeleton (e.g. Elmidae), or protective cases or cocoons (e.g. Xiphocentronidae).

Trout diets differed between ecoregions. Overall, the occurrence of allochthonous invertebrates in trout stomachs was greater in the high-Andean region than in the páramo region, where trout diet was mainly composed of aquatic invertebrates (e.g. Chironomidae, Hydropsychidae, Empididae) and, to a minor degree, by terrestrial families. The greatest distances among trout individuals (points) on the nMDS plot suggest generalist behaviors in the high-Andean region (Fig. 5). Importantly, there was no trace of piscivory, such as scales, bones, fins, rays or muscle in the dissected stomachs.

Most of the prey items had similar contributions to the trout diet (Fig. 5). Overall, both adult and juvenile trout exhibited a notable similarity in their feeding strategies in the páramo reaches. There was a generalized feeding strategy with a presumable preference for Chironomidae midges (Fig. 5). At the high-Andean reach, adults had a slightly different feeding strategy from juveniles. Adults did not show a bias towards a specific invertebrate and their diet was composed mainly by mid- or low-occurrence taxa (except for Cecidomyiidae). Juveniles fed on a lesser quantity of taxa and their diet tended to be composed of 
aquatic invertebrates such as Chironomidae and Baetidae (Fig. 5).

\section{DISCUSSION}

The distribution of the ecoregional belts has been the basis of studies that seek to understand the drivers of biodiversity patterns in the Neotropical Andes. Several studies have demonstrated that ecoregional features (e.g. evolutionary history and contemporary environmental conditions) determine species distributions and, therefore, the composition of species in local communities and metacommunities (Nottingham et al., 2018; González-Trujillo et al., 2019). Our study emphasizes that ecoregional features might also determine individual- and population-level responses of Rainbow Trout. Particularly, we observed that the diet, maximum size, sexual maturation, and feeding behavior might change depending on the ecoregion through which the river flows. Our overall results suggest that the changes in trout auto-ecology might respond to the natural absence of a riparian forest instead of river's water quality or flow conditions, since forest presence affects resource availability and water temperature (Allan et al., 2003; Lorion \& Kennedy, 2009; Eros et al., 2012).

It is known that water temperature affects the growth, physiology, development, locomotion and digestive efficiency of aquatic ectotherms such as salmonids (Azevedo et al., 1998; Myrick \& Cech., 2000; Ojanguren et al., 2001; Stiller et al., 2017). Rainbow Trout populations at the sampled reaches thrive among the acceptable ranges for this species and other salmonids (10 to $18{ }^{\circ} \mathrm{C}$, Austreng et al., 1987; Bendiksen et al., 2003; Amin et al., 2014). Although there were no differences in terms of water temperature among reaches, this parameter tended to be higher in one of the páramo reaches (Leticia), where the trout population was close to the optimal culture temperature $\left(14\right.$ to $16^{\circ} \mathrm{C}$, Table 1; Hardy 2002; Wing-Keong et al., 2010). Trout within this reach attained smaller sizes and earlier sexual maturity compared to those at the high-Andean reach. This can be explained by the temperature-size rule, which state that higher temperatures result in faster growth to a smaller size (Atkinson, 1995;
Angilletta \& Dunham, 2003). However, there are other environmental variables that can affect growth rate such as food availability and size at maturity (Angilletta \& Dunham, 2003; Angilletta et al., 2004; Arendt, 2011). Páramo reaches can present extreme changes in weather conditions throughout the day, especially of radiation and temperature (Buytaert et al., 2006; Morales et al., 2007). Thus, water temperatures between day and night and amongst ecoregions might be significantly different. Further studies should contemplate these important conditions that impose biological stress and can affect the auto-ecological characteristics such as those analyzed here.

Considering that neither the flow regime nor the physical and chemical stream properties (except conductivity) varied considerably between ecoregions, it could be hypothesized that the characteristics of the riparian forest in terms of the quantity and quality of resources that they provide probably drive the observed variability in auto-ecological characteristics. The herbaceous riparian vegetation of páramo does not provide the same broad spectrum of allochthonous prey as the high-Andean reach. Thus, it is reasonable that aquatic invertebrates - in special Chironomidae were the main components of the trout diet in the páramo reaches. Meanwhile, the broad spectrum of allochthonous prey could explain the mixed diet and feeding strategy (varying between specialization and generalization) observed in the individuals inhabiting the high-Andean reach (Amundsen, 1995; Amundsen et al., 1996).

Despite the fact that the daily and seasonal temperature regimes might have a considerable effect, it appears that the lower availability and quality of resources may have a relevant role explaining why páramo populations attain sexual maturity at shorter standard lengths compared to other rivers of the world (Bastardo, 1994; Dedual \& Collier., 1995; Oscoz et al., 2005; Arismendi et al., 2011). Slower growth of salmonids is thought to occur due to the lack of suitable prey that are sufficiently large to sustain further growth (Keeley \& Grant., 2001). According to Kawaguchi and Nakano (2001) and Webster and Hartman (2005), terrestrial prey is paramount for fish bioenergetics at headwater streams and represents nearly half of the prey consumed on a yearly basis. 
The scarce allochthonous inputs might have driven trout populations to maintain a diet of small benthic invertebrates that represent a low-quality resource compared to the larger invertebrates coming from the riparian forest. Therefore, the páramo region trout could be allocating energy towards sexual maturity instead of towards biomass accumulation, as was suggested for trout inhabiting rivers with extreme environmental conditions and lack of resources (e.g. high-altitude streams; Barros \& De Gonzo, 2004).

The partition of resources reduces trophic competition and facilitates habitat segregation (Elliott, 1973). The larger average trout size in the high-Andean population compared to populations in the páramo may be linked to behavioral partitioning of resources driven by differences in the amount of allochthonous input. Juvenile trout might take advantage of the higher diversity of benthic invertebrates in the high-Andean reach. Meanwhile, adults feed mainly on allochthonous invertebrates originating from the riparian forest. As reported by Eros et al. (2012), large dominant salmonids forage in the water column where they find and consume drifting terrestrial or aquatic invertebrates. Although we only sampled benthic invertebrates, a diet composed of allochthonous insects and aquatic invertebrates not occurring in benthic samples partially supports that larger trout fed primarily in the water column of the high-Andean reach. Epibenthic feeding requires active seeking of prey, while drift feeding relies more on current to deliver the prey to the trout. Thus, drift feeding presumably requires less energy for prey capture, allowing high-Andean trout to allocate more energy towards the individual growth (Tippets \& Moyle, 1978). Drift feeding might be an important energy source for trout (Wipfli, 1997; Romaniszyn et al., 2007; Vimos et al., 2015). However, Flecker (1992) reported a change from diurnal to nocturnal drift of macroinvertebrates in Neotropical Andean streams as a way to avoid predation from introduced Rainbow Trout. Further research should address the relationship between feeding strategies and invertebrate drift patterns, and how changes in this relationship may affect Rainbow Trout auto-ecological traits.

Andean rivers and mountain headwaters in general are oligotrophic ecosystems where the resources for maintaining high-trophic levels come from allochthonous pathways (Encalada et al., 2010). Therefore, it has been asserted that the diversity and distribution of fish communities, and other high-trophic level species are closely linked to the characteristics of the rivers' riparian forest (Polis et al., 1997; Nakano et al., 1999; Syrjänen et al., 2011; Vimos et al., 2015). Overall, our results suggest that limited availability of resources linked to ecoregional characteristics may not constrain successful trout establishment at high-Andean streams but may have a direct effect over some trout auto-ecological features such as feeding behavior, sexual maturation and maximum size. We observed that the expression of these auto-ecological features changed in parallel to the higher availability of allochthonous resources in the high-Andean ecoregion. The observed patterns could be helpful for modeling the distribution of Rainbow Trout abundance and biomass in the tropical Andean mountains, since they are closely related to the auto-ecological features examined in this paper, as has been reported and used in other countries (Jowett, 1990). Nevertheless, future studies are needed to disentangle the possible effects of changes in the thermal regime and invertebrate drift patterns on the auto-ecological traits of Rainbow Trout.

\section{ACKNOWLEDGEMENTS}

We wish to thank Universidad Nacional de Colombia, Bogotá, Parques Nacionales Naturales de Colombia (PNN) and Empresa de Acueducto y Alcantarillado de Bogotá (EAAB). Thanks to J. Donato, J. Mojica, J. Morales, Y. Abuhatab and K. Chacón for field trip assistance, and to D. Symonds and A. DeMilto for comments and suggestions. This research was approved by the ethics committee of Nacional de Colombia and all animal care guidelines were followed.

\section{FUNDING}

This study was developed as part of the Scientific and Technological Agreement (No. 1-07-243000832-2012 EAAB-ESP - UNAL) between Empresa de Acueducto y Alcantarillado de Bogotá (EAAB) and Universidad Nacional de Colombia. 


\section{REFERENCES}

ALLAN, J. D., M. S. WIPFLI, J. P. CAOUETTE, A. PRUSSIAN \& J. RODGERS. 2003. Influence of streamside vegetation on inputs of terrestrial invertebrates to salmonid food webs. Canadian Journal of Fisheries and Aquatic Sciences, 60 (3): 309-320.

AMIN, M. N., R. K. BARNES \& L. R. ADAMS. 2014. Effect of temperature and varying level of carbohydrate and lipid on growth, feed efficiency and nutrient digestibility of brook trout, Salvelinus fontinalis (Mitchill, 1814). Animal Feed Science and Technology, 193: 111-123.

AMUNDSEN, P., H. GABLER, F. STALDVIK. 1996. A new approach to graphical analysis of feeding strategy from stomach contents data modification of the Costello (1990) method. Journal of Fish Biology, 48: 607-614.

AMUNDSEN, P. 1995. Feeding Strategy of Arctic Charr (Salvelinus alpinus): General Opportunist, but Individual Specialist. Nordic Journal of Freshwater Research, 71: $150-156$.

ANGILlETTA, M. \& A. E. DUNHAM. 2003. The Temperature-Size Rule in Ectotherms: Simple Evolutionary Explanations May Not Be General. The American Naturalist, 162 (3): 332-342.

ANGILLETTA, M., T. STEURY \& M. SEARS. 2004. Temperature, Growth Rate, and Body Size in Ectotherms: Fitting Pieces of a Life-History Puzzle. Integrative and Comparative Biology, 44 (6): 498-509.

ARENDT, J. D. 2011. Size-fecundity relationships, growth trajectories, and the temperature-size rule for ectotherms. Evolution, 65 (1): 43-51.

ARISMENDI, I., J. SANZANA \& D. SOTO. 2011. Seasonal age distributions and maturity stage in a naturalized rainbow trout (Oncorhynchus mykiss Walbaum) population in southern Chile reveal an ad-fluvial life history. Annales de Limnologie - International Journal of Limnology, 47 (2): 133-140.

ATKINSON, D. 1995. Effects of temperature on the size of aquatic ectotherms: Exceptions to the general rule. Journal of Thermal Biology,
20 (1-2): 61-74.

AUSTRENG, E., T. STOREBAKKEN \& T. ÅSGÅRD. 1987. Growth rate estimates for cultured Atlantic salmon and rainbow trout. Aquaculture, 60 (2): 157-160.

AZEVEDO, P., C. YOUNG, S. LEESON \& D. BUREAU. 1998. Effects of feeding level and water temperature on growth, nutrient and energy utilization and waste outputs of rainbow trout (Oncorhynchus mykiss). Aquatic Living Resources, 11: 227-238.

BARROS, S., G. GONZO. 2004. Poblaciones naturalizadas de truchas arco iris (Oncorhynchus mykiss) en la Puna de Argentina: bases ecológicas para su manejo. Memorias: manejo de fauna silverstre en Amazonía $y$ Latinoamérica, 2 (4400): 125-135.

BASTARDO, H. 1994. Reproducción y talla media de madurez de la trucha Oncorhynchus mykiss (Salmoniformes: Salmonidae) en los Andes venezolanos. Revista de Biología Tropical, 42 (1/2): 263-270.

BAXTER, C., K. FAUSCH, M. MURAKAMI \& P. CHAPMAN. 2004. Fish Invasion Restructures Stream and Forest Food Webs by Interrupting Reciprocal Prey Subsidies. Ecology, 85 (10): 2656-2663.

BAXTER, C. V., K.D. FAUSCH \& W. C. SAUNDERS. 2005. Tangled webs: Reciprocal flows of invertebrate prey link streams and riparian zones. Freshwater Biology, 50 (2): 201-220.

BEHNKE, R. 1992. Native trout of Western North America. Monograph 6, American Fisheries Society. Bethesda, Maryland.

BENDIKSEN, E. Å., O. K. BERG, M. JOBLING, A. M. ARNESEN \& K. MÅSØVA. 2003. Digestibility, growth and nutrient utilisation of Atlantic salmon parr (Salmo salar L.) in relation to temperature, feed fat content and oil source. Aquaculture, 224 (1-4): 283-299.

BUYTAERT, W., R. CÉLLERI, B. DE BIÈVRE, F. CISNEROS, G. WYSEURE, J. DECKERS \& R. HOFSTEDE. 2006. Human impact on the hydrology of the Andean paramos. Earth-Science Reviews, 79 (1-2): 53-72.

CAMBRAY, J. A. 2003. Impact on indigenous species biodiversity caused by the globalisa- 
tion of alien recreational freshwater fisheries. Hydrobiologia, 500: 217-230.

DEDUAL, M. \& K. J. COLLIER. 1995. Aspects of juvenile rainbow trout (Oncorhynchus mykiss) diet in relation to food supply during summer in the lower Tongariro River, New Zealand. New Zealand Journal of Marine and Freshwater Research, 29 (3): 381-391.

DOMÍNGUEZ, E. \& H. FERNÁNDEZ. 2009. Macroinvertebrados bentónicos sudamericanos. Sistemática y Biología. Fundación Miguel Lillo. Tucumán, Argentina.

ELLIOTT, J. M. 1973. The food of brown and rainbow trout (Salmo trutta and $S$. gairdneri) in relation to the abundance of drifting invertebrates in a mountain stream. Oecologia, 12 (4): 329-347.

ENCALADA, A. C., J. CALLES, V. FERREIRA, C. M. CANHOTO \& M. A. S. GRAÇA. 2010. Riparian land use and the relationship between the benthos and litter decomposition in tropical montane streams. Freshwater Biology, 55 (8): 1719-1733.

EROS, T., P. GUSTAFSSON, L. A. GREENBERG \& E. BERGMAN. 2012. Forest-stream linkages: Effects of terrestrial invertebrate input and light on diet and growth of brown trout (Salmo trutta) in a boreal forest stream. PLoS ONE, 7 (5).

FAUSCH, K. D. 2007. Introduction, establishment and effects of non-native salmonids: considering the risk of rainbow trout invasion in the United Kingdom. Journal of Fish Biology, 71: 1-32.

FLECKER, A. 1992. Fish predation and the evolution of invertebrate drift periodicity Evidence from Neotropical streams. Ecology, 73 (2): 438-448.

FLECKER, A. \& C. TOWNSEND. 1994. Community-Wide Consequences of Trout Introduction in New Zealand Streams. Ecological Applications, 4 (4): 798-807.

GONZÁlEZ-TRUJILlO, J. D., J. C. DONATO-RONDON, O. MUÑOZ \& S. SABATER. 2020. Historical processes constrain metacommunity structure by shaping different pools of invertebrate taxa within the Orinoco basin. Diversity and Distributions, 26 (1): 49-61.
HARDY, R. 2002. Rainbow trout, Oncorhynchus mykiss. In: Nutrient Requirements and Feeding of Finfish for Aquaculture. C. D. Webster and C. Lim (eds.): 184-202. CABI Publishing. Wallingford, United Kingdom.

HORN, H. S. 1966. Measurement of "overlap" in Comparative Ecological Studies. The American Naturalist, 100 (914): 419-424.

HUMBOLDT, A. von \& A. BONPLAND. 1805. Essai sur la géogaphie des plantes. S. et C. Levrault, Chez (ed.). Paris.

HYSLOP, E. J. 1980. Stomach contents analysis-a review of methods and their application. Journal of Fish Biology, 17: 411-429.

IDEAM. 2010. Sistemas morfofénicos del territorio Colombiano. Instituto de Hidrología, Meteorología y Estudios Ambientales. Bogotá, D.C.

JOHNSON, N. \& C. A. TRIPPLEHORN. 2005. Borror and Delong's introduction to the study of insects. Brooke Cole. Belmont, California.

JOST, L., A. CHAO \& R. CHAZDON. 2011. Compositional similarity and $\beta$ (beta) diversity. In: Biological diversity: frontiers in measurement and assessment. A. Magurran and B. McGill (eds.): 66-87. Oxford University Press. New York.

JOWETT, I. G. 1990. Factors related to the distribution and abundance of brown and rainbow trout in new zealand clear-water rivers. New Zealand Journal of Marine and Freshwater Research, 24 (3): 429-440.

KAWAGUCHI, I. \& S. NAKANO. 2001. Contribution of terrestrial invertebrates to the annual resource budget for salmonids in forest and grassland reaches of a headwater stream. Freshwater Biology, 46: 303-316.

KEELEY, E. R. \& J. W. GRANT. 2001. Prey size of salmonid fishes in streams, lakes, and oceans. Canadian Journal of Fisheries and Aquatic Sciences, 58 (6): 1122-1132.

KITANO, S. 2004. Ecological impacts of rainbow, brown and brook trout in Japanese inland waters. Global Environmental Research, 8: 41-50.

LORION, C. M. \& B. P. KENNEDY. 2009. Riparian Forest Buffers Mitigate the effects of Deforestation on Fish Assemblages in Tropical Headwater Streams. Ecological Applica- 
tions, 19 (2): 468-479.

MACCHI, P. J., V. E. CUSSAC, M. F. ALONSO $\&$ M. A. DENEGRI. 1999. Predation relationships between introduced salmonids and the native fish fauna in lakes and reservoirs in northern Patagonia. Ecology of Freshwater Fish, 8 (4): 227-236.

MORALES, M., J. OTERO, T. VAN DER HAMMEN, A. TORRES, C. CADENA, C. PEDRAZA, N. RODRÍGUEZ, C. FRANCO, J. BETANCOURTH, E. OLAYA, E. POSADA \& L. CÁRDENAS. 2007. Atlas de Páramos de Colombia. Instituto de investigación de Recursos Biológicos Alexander von Humboldt. Bogotá, D.C.

MORISITA, M. 1959. Measuring of Interspecific Association and Similarity Between Communities. Memoirs of the Faculty of Science, Kyushu University, Series E (Biology), 3 (1): 65-80.

MYRICK, C. A. \& J. J. CECH. 2000. Temperature influences on California rainbow trout physiological performance. Fish Physiology and Biochemistry, 22 (3): 245-254.

NAKANO, S., H. MIYASAKA \& N. KUHARA. 1999. Terrestrial - Aquatic Linkages: Riparain Arthropod Inputs Alter Trophic Cascades in a Stream Food Web. Ecology, 80 (7): 2435-2441.

NOTTINGHAM, A. T., N. FIERER, B. L. TURNER, J. WHITAKER, N. J. OSTLE, N. P. MCNAMARA, R. D. BARDGETT, J. W. LEFF, N. SALINAS, M. R. SILMAN, L. E. B. KRUUK \& P. MEIR. 2018. Microbes follow Humboldt: temperature drives plant and soil microbial diversity patterns from the Amazon to the Andes. Ecology, 99 (11): 2455-2466.

OJANGUREN, A. F., F. G. REYES-GAVILÁN \& F. BRAÑA. 2001. Thermal sensitivity of growth, food intake and activity of juvenile brown trout. Journal of Thermal Biology, 26 (3): 165-170.

OSCOZ, J., P. M. LEUNDA, F. CAMPOS, M. C. ESCALA \& R. MIRANDA. 2005. Spring diet composition of Rainbow Trout, Oncorhynchus mykiss (Walbaum, 1792) in the Urederra River (Spain). Annales de Limnologie - International Journal of Limnology, 41 (1): 27-34.
PASCUAL, M., P. MACCHI, J. URBANSKI, F. MARCOS, C. RIVA ROSSI, M. NOVARA \& P. DELL'ARCIPRETE. 2002. Evaluating potential effects of exotic freshwater fish from incomplete species presence-absence data. Biological Invasions, 4 (1-2): 101-113.

PINEDA, H., J. E. JARAMILLO PINO, D. M. ECHEVERRI \& M. OLIVERA. 2004. Cultivo de trucha arcoiris. Posibilidades en Colombia. Revista Colombiana de Ciencias Pecuarias, 17 (40): 45-52.

POLIS, G. A., W. B. ANDERSON \& R. D. HOLT. 1997. Toward an integration of landscape and food web ecology: The Dynamics of Spatially Subsidized Food Webs. Annual Review of Ecology and Systematics, 28 (1): 289-316.

PRAT, N., M. RIERADEVALL, R. ACOSTA \& C. VILLAMARIN. 2011. Guía para el reconocimiento de las larvas de Chrinomidae (Diptera) de los ríos altoandinos de Ecuador y Perú. Grupo de investigación FEM, Departamento de Ecología. Universidad de Barcelona. Barcelona, España.

R Core team. 2015. R: A Language and Environment for Statistical Computing. R Foundation for Statistical Computing. Available from: http://www.r-project.org.

RAHEL, F. J. 2000. Homogenization of Fish Fauna Across the United States. Science, 288 (5467): 854-856.

RANGEL-CH, O., P. LOWY-C \& M. AGUILAR-P. 1997. Distribución de los tipos de vegetación en las regiones naturales de Colombia. In: Colombia Diversidad Biotica II. Tipos de vegetacion en Colombia. O. Rangel-Ch (ed.): 383. Universidad Nacional de Colombia. Bogotá, D.C.

ROMANISZYN, E. D., J. J. HUTCHENS \& J. BRUCE WALLACE. 2007. Aquatic and terrestrial invertebrate drift in southern Appalachian Mountain streams: Implications for trout food resources. Freshwater Biology, 52 (1): $1-11$.

SEGNINI, S., H . BASTARDO. 1995. Cambios Ontogeneticos en la Dieta de la Trucha Arcoiris (Oncorhynchus mykiss) en un Rio Andino Neotropical. Biotropica, 27 (4): 495-508. 
SIMON, K. S. \& C. R. TOWNSEND. 2003. Impacts of freshwater invaders at different levels of ecological organisation, with emphasis on salmonids and ecosystem consequences. Freshwater Biology, 48 (6): 982-994.

SOTO, D., I. ARISMENDI, J. GONZÁLEZ, J. SANZANA, F. JARA, C. JARA, E. GUZMAN \& A. LARA. 2006. Southern Chile, trout and salmon country: Invasion patterns and threats for native species. Revista Chilena de Historia Natural, 79 (1): 97-117.

STILLER, K. T., K. H. VANSELOW, D. MORAN, G. RIESEN, W. KOPPE, C. DIETZ \& C. SCHULZ. 2017. The effect of diet, temperature and intermittent low oxygen on the metabolism of rainbow trout. British Journal of Nutrition, 117 (6): 784-795.

SYRJÄNEN, J., K. KORSU, P. LOUHI, R. PAAVOLA, T. MUOTKA \& J. ROSENFELD. 2011. Stream salmonids as opportunistic foragers: the importance of terrestrial invertebrates along a stream-size gradient. Canadian Journal of Fisheries and Aquatic Sciences, 68 (12): 2146-2156.

TIPPETS, W. \& P. MOYLE. 1978. Epibenthic Feeding by Rainbow Trout (Salmo gairdneri) in the McCloud River, California. Journal of
Animal Ecology, 47 (2): 549-559.

TOWNSEND, C. R. 2003. Individual, population, community, and ecosystem consequences of a fish invader in New Zealand streams. Conservation Biology, 17 (1): 38-47.

VIMOS, D. J., A. C. ENCALADA, E. SUÁREZ $\&$ N. PRAT. 2015. Effects of exotic trout on benthic communities in high-Andean tropical streams. Freshwater Science, 34 (2): 770-783.

WEBSTER, J. J. \& K. J. HARTMAN. 2005. The role of terrestrial invertebrates in allopatric brook trout headwater streams in the Central appalachian mountains. Journal of Freshwater Ecology, 20 (1): 101-107.

WING-KEONG, N., B. CODABACCUS, C. CARTER \& P. NICHOLS. 2010. Replacing dietary fish oil with palm fatty acid distillate improves fatty acid digestibility in rainbow trout, Oncorhynchus mykiss, maintained at optimal or elevated water temperature. Aquaculture, 309 (1-4): 165-172.

WIPFLI, M. S. 1997. Terrestrial invertebrates as salmonid prey and nitrogen sources in streams: contrasting old-growth and young-growth riparian forests in Southeastern Alaska, U.S.A. Canadian Journal of Fisheries and Aquatic Sciences, (54): 1259-1269. 